\title{
Effect of dwelling time and plunge depth on the joint properties of the dissimilar friction stir spot welded aluminum and steel
}

\author{
Mohamed M.Z. Ahmed***, Mahmoud A. Abdu Abdul-Maksoud **, Mohamed M. El-Sayed \\ Seleman ** and Adel M. A. Mohamed ** \\ * Mechanical Engineering Department, College of Engineering at Al Kharj, Prince Sattam Bin Abdulaziz University, Al Kharj 16273, KSA. \\ **Metallurgical and Materials Engineering Department, Faculty of Petroleum and Mining Engineering. Suez University, Suez 43511, Egypt. \\ *Corresponding Author: moh.ahmed@psau.edu.sa
}

Submitted : 15/08/2020

Revised : 23/01/2021

Accepted :04/02/2021

\begin{abstract}
Sound joints of a far apart property, pure aluminum and mild steel, and dissimilar materials were obtained by friction stir spot welding (FSSW) solid state joining process. Sheets of $2 \mathrm{~mm}$ thickness were overlapped and fixed with a fixture device then welded. Welding parameters that produced the sound joint were identified. Joints microstructure and mechanical properties were investigated. A microstructural investigation has revealed a creation of mechanical interlocking and discontinuous formation of the intermetallic compounds found at the interface. The intermetallic compound (IMC) layer thickness ranged from $6 \mu \mathrm{m}$ to $17 \mu \mathrm{m}$ with the optimum condition specimen, $800 \mathrm{rpm}$ and $5 \mathrm{Sec}$ dwell time. Tensile-shear test showed that failure load has increased with increasing tool plunge depth and rotational speed. After the optimum value of rotational speed, the shear failure load decreased. The maximum shear failure load of $2.15 \mathrm{KN}$ was attained at $800 \mathrm{rpm}$ and $2.4 \mathrm{~mm}$ plunge depth.
\end{abstract}

Keywords: Aluminum alloy AA1050; Friction stir spot welding (FSSW); dissimilar welding; Mild steel; Microstructure; Tensile shear test.

\section{INTRODUCTION}

Dissimilar materials, for example, aluminum and steel, have both different physical and mechanical properties. Automotive industry used aluminum with steel hybrid constructions, such as transportation vehicles, to offer combined benefits of strength and light weight (Reza-E-Rabbya et al., 2020). Butt joining these disparate materials with conventional fusion welding is a challenge and it requires other welding innovations. Friction stir welding (FSW) is presented as problem solving technology for such applications (Khodir et al., 2016; Ahmed et al., 2016; Hoziefa et al., 2016). Recently, friction stir spot welding (FSSW) is noted to be one of the best alternatives in industry (Ahmed et al., 2016) for the currently used resistance spot welding (Ataya, 2014a). FSSW provides great advantages for dissimilar materials joining, compared to typical fusion welding processes (Ahmed et al., 2016; Figner et al., 2009). FSSW has three main steps which are illustrated in Figure 1. In the first step, a rotating nonconsumable tool with a pin is plunged into the two sheet plates, which are in a lap configuration. Also, there is a backing strip, or anvil, that 
contacts the lower sheet from th bottom and supports the axial load made by the welding tool during the welding cycle (Bozzi et al., 2008).

Feasibility of FSSW to weld aluminum to steel was shown by Piccini and Svoboda (2015) who joined AA6063 with galvanized low carbon steel by FSSW, and studied the effect of tool configuration on the joint interface features (Ahmed et al., 2019). Fereiduni, Movahedi, and Kokabi (2016) attempted a joining of AA5083 and St-12 steel alloy sheets by an alternate FSSW and found that the shear strength decrease is due to the formation of intermediate phases. Also, Mahto et al. (2016) studied the FSSW parameters effect on the mechanical properties of AA 6061-T6 and stainless steel spot joints and observed the presence of intermetallic compounds at the interface through metallurgical bonds. Welding time and rotational speed are main factors for increasing friction heating resulting in formation of a brittle intermetallic compound (IMC) by interface reaction between aluminum and ferrous metals (Aota, Takahashi, and Ikeuchi, 2010; Abd et al., 2020). So, it is very important to control and decrease the welding time to a few seconds. Thus, the aim of this work is to investigate the effect of FSSW dwelling time ( $\mathrm{t}$ ) and plunge depth (Pd) on the joint strength and microstructure of the dissimilar friction stir spot welded aluminum and steel.
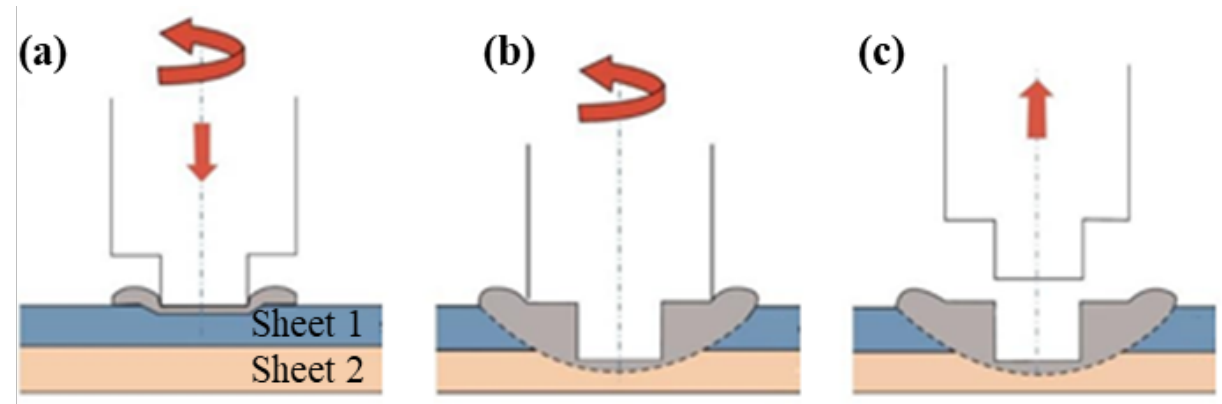

Figure 1. Schematic of the FSSW process stages:

(a) FSSW tool rotating; (b) plunging and dwelling step; (c) retraction (Yang, Fu, and Li, 2014).

\section{EXPERIMENTAL PROCEDURE}

\section{Materials and FSSW}

The materials used in this work were sheets of commercial pure aluminum alloy (AA 1050) and low carbon steel (mild steel) with chemical composition presented in Table 1 . Two work-pieces of $2 \mathrm{~mm}$ thickness were cut with dimensions of $150 \mathrm{~mm}$ length $\times 30 \mathrm{~mm}$ width. Figure 2 shows the schematic of the lap joint configuration. The two sheets were overlapped with $30 \mathrm{~mm}$ by $30 \mathrm{~mm}$ overlap area. The upper and lower sheets were aluminum alloy AA1050 and mild steel, respectively. Figure 3 shows the special fixture that was designed and manufactured to be used in the FSSW process to assure the lap joint alignment and to conduct a series of spots sequentially to reduce welding setting time. Clamps' screw bolts were tightened to prevent the work-piece from pulling up. The FSSW were carried out using a computerized (EG-FSW-M1) at Suez University. The used rotating tool was cylindrical tool with a semispherical pin made of $\mathrm{H} 13$ tool steel type. The cylindrical tool consists of shoulder with diameter of $20 \mathrm{~mm}$ and probe of $4 \mathrm{~mm}$ diameter and $0.4 \mathrm{~mm}$ length and no tilting angle was applied to the tool. FSSW was performed at three rotation rates of $400 \mathrm{rpm}, 800 \mathrm{rpm}$, and $1200 \mathrm{rpm}$, and five dwelling times of $2.5 \mathrm{~s}, 5 \mathrm{~s}, 7.5 \mathrm{~s}, 10 \mathrm{~s}$, and $12.5 \mathrm{~s}$ were applied. Also two plunge depths of $1.4 \mathrm{~mm}$ and $2.4 \mathrm{~mm}$ as nonpenetrating and penetrating of lower mild steel were used. The plunge rate of $0.1 \mathrm{~mm} / \mathrm{sec}$ used in all experiments was constant. The FSSW conditions used in this work are presented in Table 2. 
Table 1. Chemical composition in weight $\%$ of aluminum and low carbon steel sheet.

\begin{tabular}{|c|c|c|c|c|c|c|c|c|c|c|c|c|}
\hline \multirow{2}{*}{$\begin{array}{c}\text { AA } \\
1050\end{array}$} & $\mathbf{S i}$ & $\mathrm{Fe}$ & Mg & Mn & $\mathbf{T i}$ & $\mathbf{V}$ & $\mathrm{Cu}$ & $\mathrm{Cr}$ & \multicolumn{2}{|c|}{$\begin{array}{c}\text { Other } \\
\text { Impurities } \mathrm{Ni} \text {, } \\
\text { Zn, and } \mathrm{Sn}\end{array}$} & \multicolumn{2}{|l|}{ Al } \\
\hline & 0.228 & 0.268 & 0.82 & 0.077 & 0.015 & 0.011 & 0.009 & 0.0005 & \multicolumn{2}{|c|}{$\begin{array}{l}\text { Single }<0.001 ; \\
\quad \text { total } 0.003\end{array}$} & \multicolumn{2}{|l|}{ Balance } \\
\hline \multirow{2}{*}{$\begin{array}{c}\text { Low C } \\
\text { steel }\end{array}$} & $\mathrm{C}$ & Mn & $\mathrm{Cu}$ & $\mathbf{S i}$ & $\mathbf{W}$ & Al & $\mathbf{V}$ & Nb & $\mathbf{P}$ & $\mathbf{S}$ & $\begin{array}{c}\mathrm{Zr}, \mathrm{B}, \mathrm{Sn}, \mathrm{As}, \\
\mathrm{Pb}, \mathrm{Mo}, \mathrm{Co}, \mathrm{Ti}, \\
\quad \mathrm{Ni}, \text { and Cr}\end{array}$ & $\mathrm{Fe}$ \\
\hline & 0.105 & 0.78 & 0.084 & 0.042 & 0.040 & 0.038 & 0.038 & 0.036 & 0.033 & 0.018 & $\begin{array}{l}\text { Single }<0.0109 \\
\quad \text { total } 0.106\end{array}$ & Balance \\
\hline
\end{tabular}

Table 2. FSSW parameters applied in this work and nomenclature.

\begin{tabular}{|c|c|c|c|}
\hline $\begin{array}{c}\text { Welding } \\
\text { condition }\end{array}$ & $\begin{array}{c}\text { Rotational speed } \\
\text { (rpm) }\end{array}$ & $\begin{array}{c}\text { Dwell time } \\
\text { (Sec) }\end{array}$ & $\begin{array}{c}\text { Plunge depth } \\
\text { (mm) }\end{array}$ \\
\hline $400-2.5$ & 400 & 2.5 & 1.4 \\
\hline $400-5$ & 400 & 5 & 1.4 \\
\hline $400-5-2$ & 400 & 5 & 2.4 \\
\hline $400-7.5$ & 400 & 7.5 & 1.4 \\
\hline $800-5$ & 800 & 5 & 1.4 \\
\hline $800-5-2$ & 800 & 5 & 2.4 \\
\hline $800-7.5$ & 800 & 7.5 & 1.4 \\
\hline $800-10$ & 800 & 10 & 1.4 \\
\hline $1200-5$ & 1200 & 5 & 1.4 \\
\hline $1200-5-2$ & 1200 & 5 & 2.4 \\
\hline $1200-10$ & 1200 & 10 & 1.4 \\
\hline $1200-12.5$ & 1200 & 12.5 & 1.4 \\
\hline
\end{tabular}

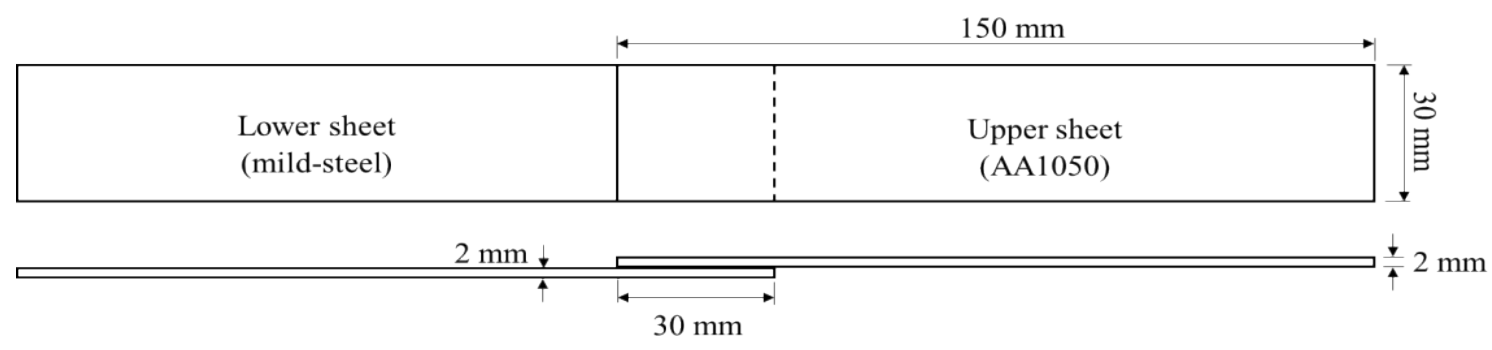

Figure 2. Schematic of the FSSW configuration with dimensions of the lap joint. 


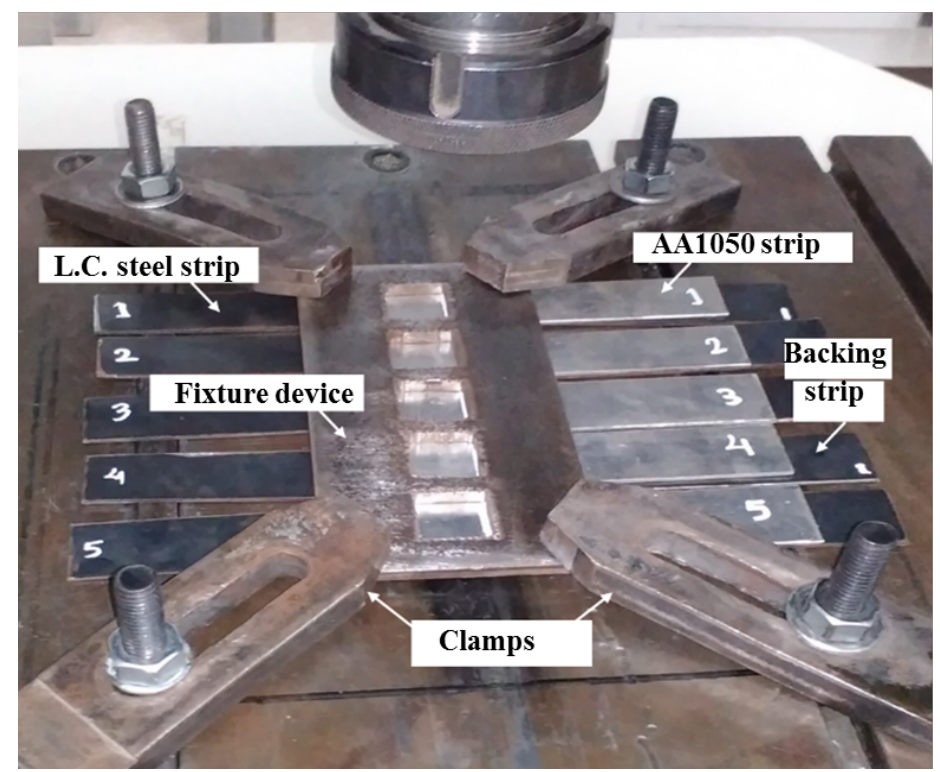

Figure 3. An image of the FSSW setup that allows a series of spots that can ran automatically.

\section{Joints Evaluation}

After FSSW, the joints are examined longitudinally using tensile shear test. For this purpose, two backing sheets were used to ensure the axial loading during the tensile shear test. Tensile shear was carried out using an INSTRON 4210 universal testing machine at room temperature. Gauge length ranges from 199 to $220 \mathrm{~mm}$ ) and loading rate 0.1 $\mathrm{mm} / \mathrm{sec}$. Fracture surfaces were examined to show the failure modes. For the hardness testing and optical microscope investigations, the FSSWed joints were sectioned across the spot using a wire electrical discharge machining (WEDM), cold mounted, then grinded, and polished according to the standard metallographic procedures. Vickers microhardness tests were performed on the transverse cross-section of FSSWed samples. Hardness measurements were carried out using a Qness Vickers hardness testing machine, model 'Q10 M'. The hardness profile was generated according to the ASTM E-384 test method using a load of $1000 \mathrm{gf}$ on the sample lower and upper sections of the mild steel and AA1050, respectively. Microstructural examination was carried out using 'Olympus DP73' optical microscope. The mild steel was etched by $2 \% \mathrm{HNO} 3$ in distilled water (nital $2 \%$ solution), and then it was washed and dried for optical microscopy (OM) investigation.

\section{RESULTS AND DISCUSSION}

\section{Downward Force History along Plunge Distance}

Figure 4 shows the typical downward plunge force curve, which can be roughly divided into four regions among five points of tool plunge distance values. The force peak value was at point $5(\mathrm{Pd}=2.4 \mathrm{~mm})$; that is, tool penetrates $0.4 \mathrm{~mm}$ into steel. At point 1 , the tool pin plunged into the upper sheet, and aluminum stirred around the pin (Hamada et al., 2015). More deformed material requires more downward plunge force. From point 1 to point 2, the tool pin plunged deeper, so high heat generated from both friction and plastic deformation which causes softening and results in a decreasing plunge force. At point 2, the tool shoulder begins to penetrate, causing the downward plunge force to increase. At point 3 , the rotating shoulder moves deeper into aluminum and squeezes it out, causing more aluminum to deform under its area and the downward force became higher. At point 4, the tool pin touches the lower steel sheet, 
and the squeezed aluminum is further suppressed by shoulder and steel sheet. Therefore, plunge force increases rapidly. Finally, after point 5, the dwell period decreases the force and then tool retracts out of the two sheets (Chen, Liu, and $\mathrm{Ni}, 2017)$.

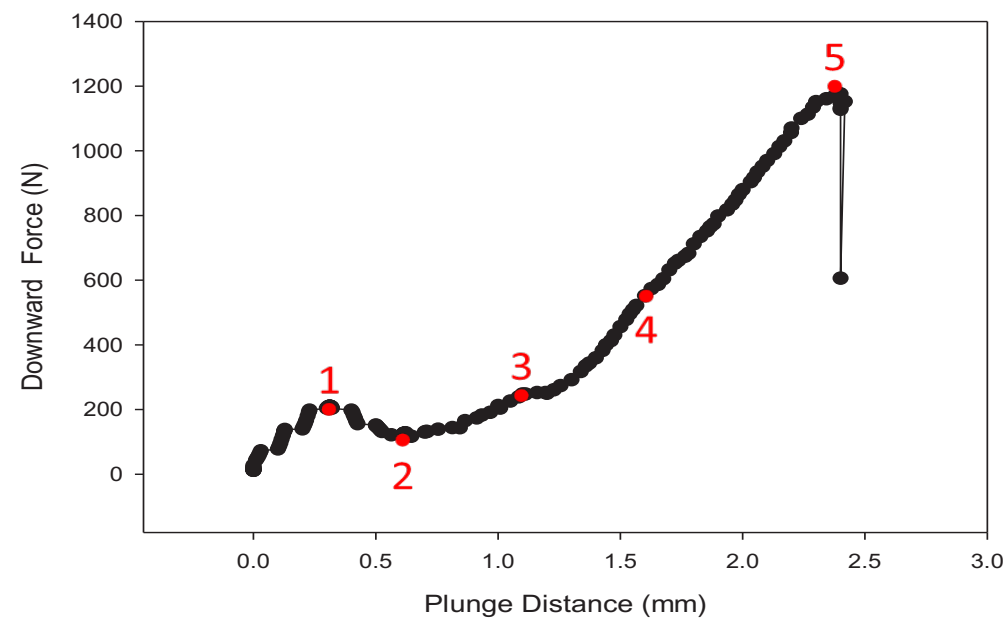

Figure 4. Downward plunge force history curve for specimen 800-5-2.

\section{Effect of Welding Parameter on Downward Force}

Downward forging force is the reaction of the tool pin and shoulder penetration into upper and lower plates. The main dominant welding parameters which have significant effect on downward forging force are the rotational speed and dwell time. Figure 5 (a) shows that the maximum plunging force values rapidly decrease with increasing the rotational speed at different dwell time values. Also, downward force decreased with increasing dwell time at different rotational speeds as shown in Figure 5 (b). Longer dwell time or higher rotational speed results in higher heat input which raises the temperature distribution (Ahmed et al., 2021a) and more material plasticization that facilitates the forging process and leads to significant reduction in forging force (Mahgoub et al., 2015). The effect of both rotational speed and dwell time is shown in Figure5 (c).

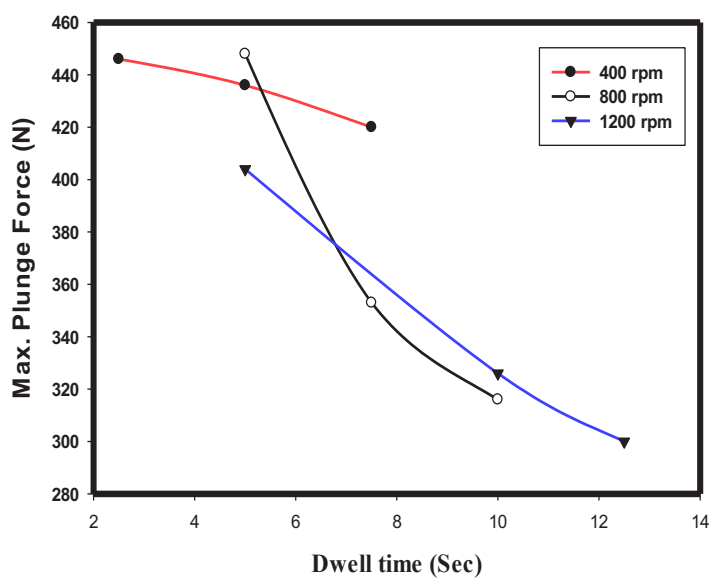

(a)

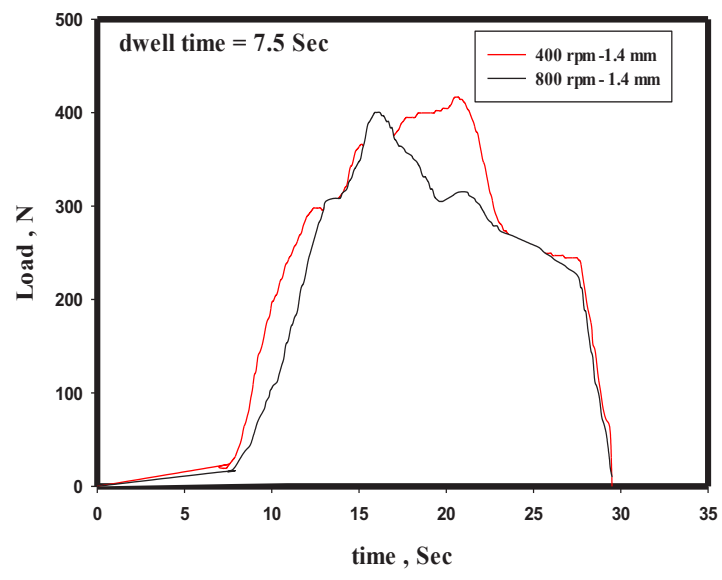

(b) 


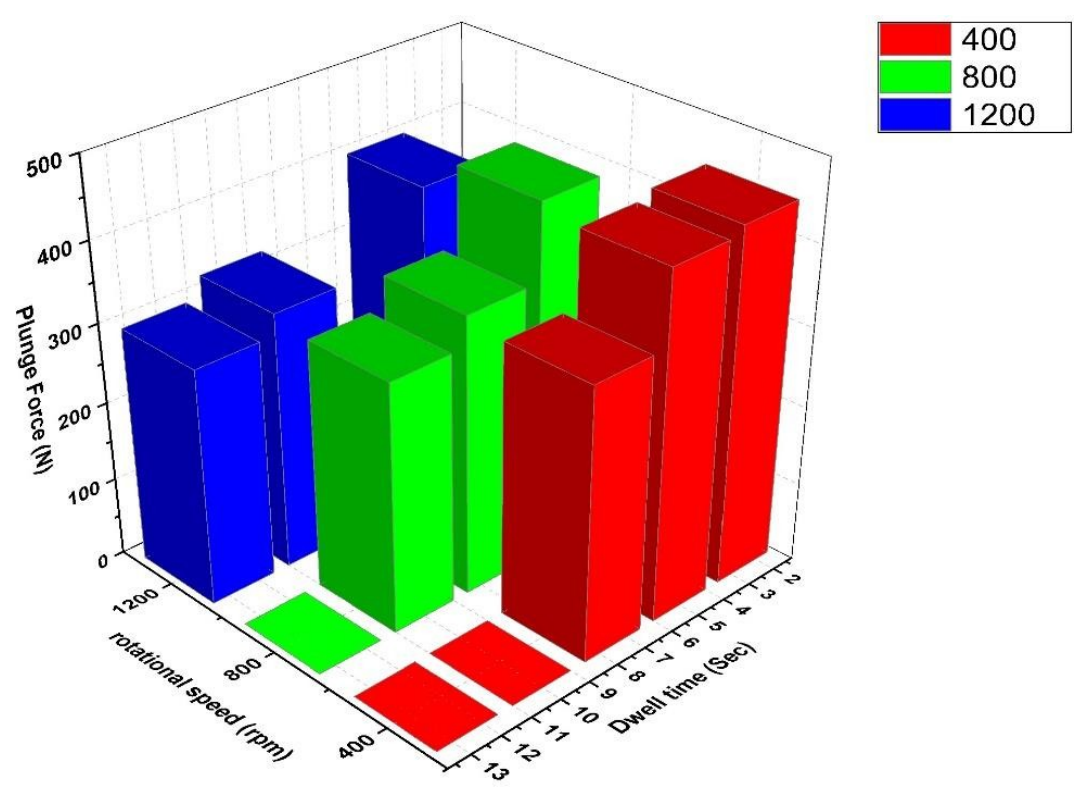

(c)

Figure 5. Effect of welding parameters on downward plunging force: a) rotational speed, b) dwell time, and c) both rotational speed and dwell time effects.

\section{Joint Appearance and Weld Structure}

The rotation speed and dwell time affect the softening of the welded material and the welding downward force enhances the stirring action (Jordon et al., 2019). Figure 6 shows the FSSWed lap joint specimen typical appearances at different welding conditions. Figure 6 (a-c) is for specimens 400-5-2, 800-5-2, and 1200-5-2 lap joints. Figure 6 (d) is for specimen (1200-5). The top view, illustrated in Figure 6 (e-h), shows the shape of the joint spot, which is circular indentation with small ring shaped projection along its outer edge. Figure $6(\mathrm{e}-\mathrm{h})$ shows same specimens back view, which has an unblemished surface and darker hot spot as a result of heat effect. Figure 6 (i-1) shows side view image of lap joint alignment which is assured by the special fixture to obtain sound joint. Sound FSSWed joints were successfully produced at optimum combination of rotational speed and dwell time. Other weak bonded specimens have visual macroscopic separation at the interface observed by visual inspection, as can be seen in Figures 7 (b), (d), and (f). AA1050/mild steel FSSW joint cross-sectional macrographs show an indentation profile of the joint which reflects the shape of semispherical pin and cylindrical shoulder of the tool as extruded material flashed to the sides of the welding line. When dwell time increased, the sound joint was obtained. However, with highly excess dwell time, the joint was weakly bonded and easily detached by very low exerted force. Dwell time optimum value was found to be $5 \mathrm{sec}$. 

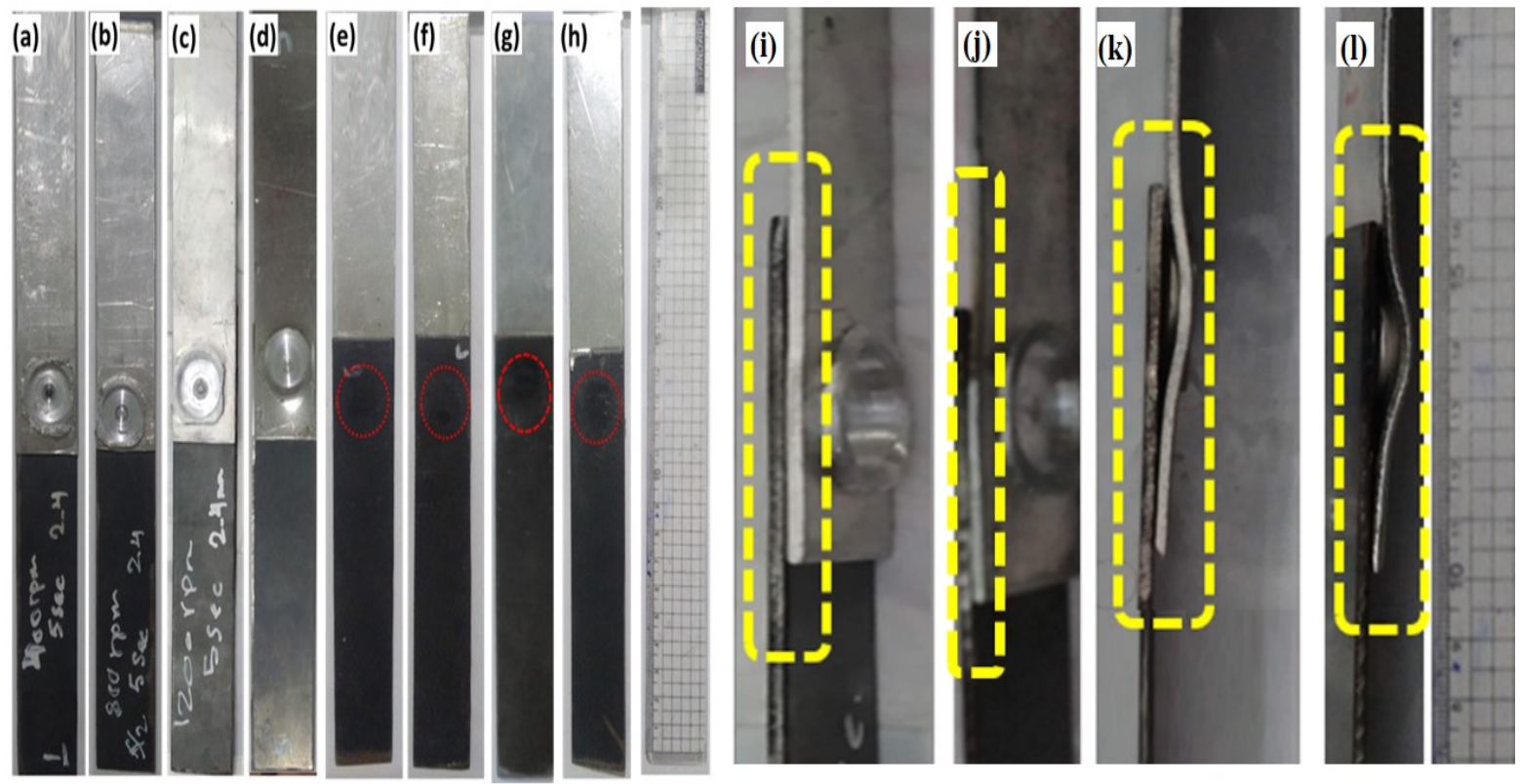

Figure 6. Welded lap joint specimens shapes 400-5-2, 800-5-2, 1200-5-2, and 1200-5. Hence (a), (b), (c), and (d) are top view. And (e), (f), (g), and (h) are back view. And (i), (j), (k), and (l) are side view of specimens 12005-2 and 1200-5. One can see (i), (j) and (k), (l) without fixture device application.
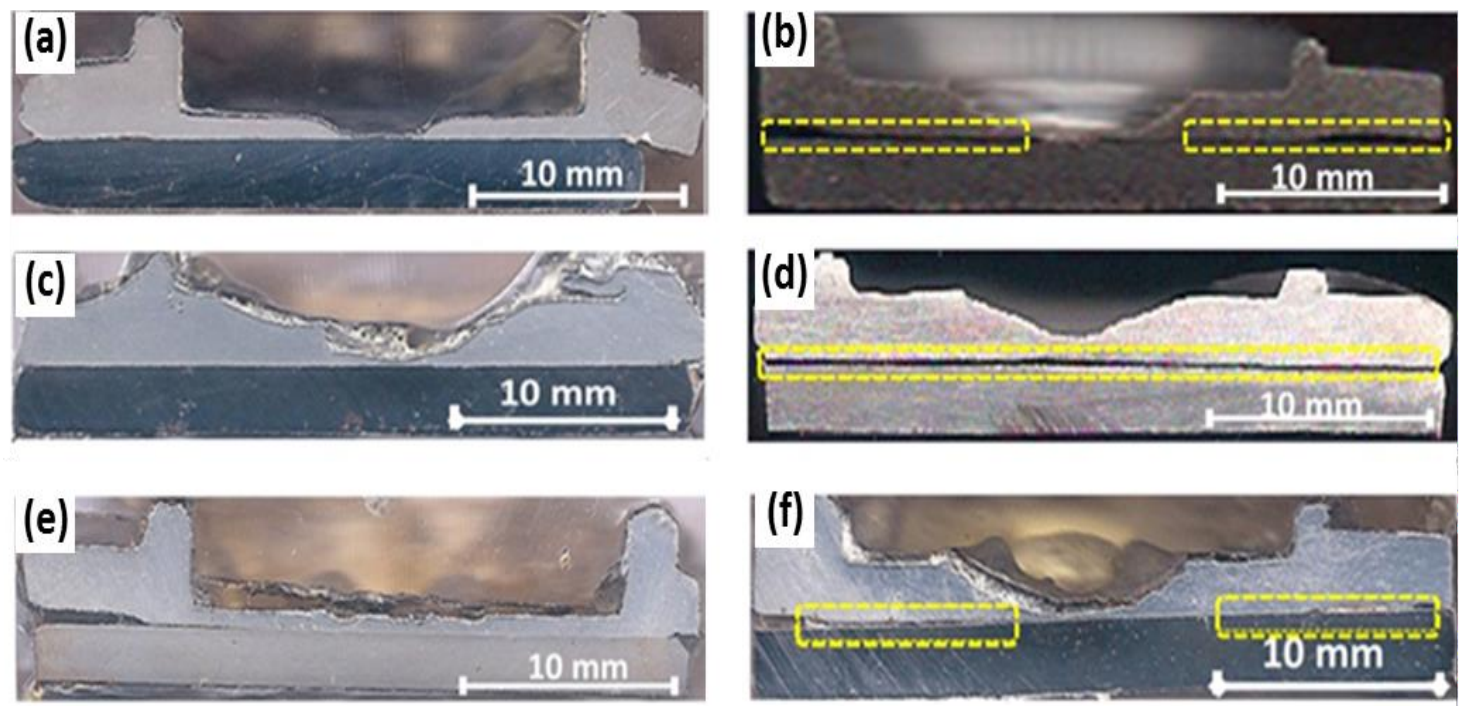

Figure 7. Cross-sections of welded FSSW specimens at conditions (a) 1200-5; (b) 1200-12.5;

(c) 400-7.5; (d) 800-7.5; (e) 800-5; and (f) 400-2.5. The separations are marked with yellow dots. 


\section{Optical Microstructure}

The optical microstructure was examined or the sound FSSWed lap joints specimens welded at 400-5-2 and 800-5-2. One of the obvious features that can be seen at the nugget zone is the 'formation of hook' from steel into aluminum. A similar hook feature was reported by Bozzi et al. (Bozzi et al., 2010). Figures 8 (c), (d), (p), and (q) show an upward hook which is a characteristic feature of the weld boundary of the FSSW joint. The hook is a partially metallurgical bond (Chen, Liu, and $\mathrm{Ni}, 2017$ ) between the two different materials. In the present work, the hook feature was detected at all penetrating $(\mathrm{Pd}=2.4 \mathrm{~mm})$ joint conditions. Other researchers reported this phenomenon in the FSW and FSSW lap joints (Babu et al., 2012).

At the upper side of the hook, the swirl structures of grains can be observed in Fig. 8 (e-f), presenting an enlarged view of the hook upper side. It can be observed that the hotter steel flows upward and extruded due to the downward squeezing motion of the pin. After a while, the steel upward flow is restrained by the tool shoulder surface larger compression force resulting in both bending steel as hook and as more layers of steel grains are extruded, a periodic vortex morphology, swirl structure, can be observed at the top side of the hook (Chen, Liu, and Ni, 2017). Discontinuous intermetallic compounds (IMCs) formation at both the interface and the top of the hook is another feature that can be observed. The embedded aluminum particles react with the steel under a certain temperature and pressure, which results in the formation of IMC within a very short welding time (Abd et al., 2020). As observed in Fig. 8 (i-n), there is a formation of IMCs in continuous and discontinuous morphology at the $\mathrm{Al} / \mathrm{mild}$ - steel interface. Some authors represented that the metallurgical bonds are formed as a result of atomic diffusion across the joint interface (Fereiduni, Movahedi, and Kokabi, 2016). Al/Fe intermetallic compounds will be formed as a consequence of the atomic diffusion if enough energy is provided at the joint interface (Fereiduni, Movahedi, and Kokabi, 2016). Fig. 8 (1) shows a high IMC thickness measured at the top of the hook. High rotational speeds make the very hot steel to flow upwards into the upper aluminum film at the interfacial area which could explain why high IMC quantity is in areas where the penetration depth increases, and the hooks extend with longer IMC (Fereiduni, Movahedi, and Kokabi, 2016; Jordon et al., 2019). 

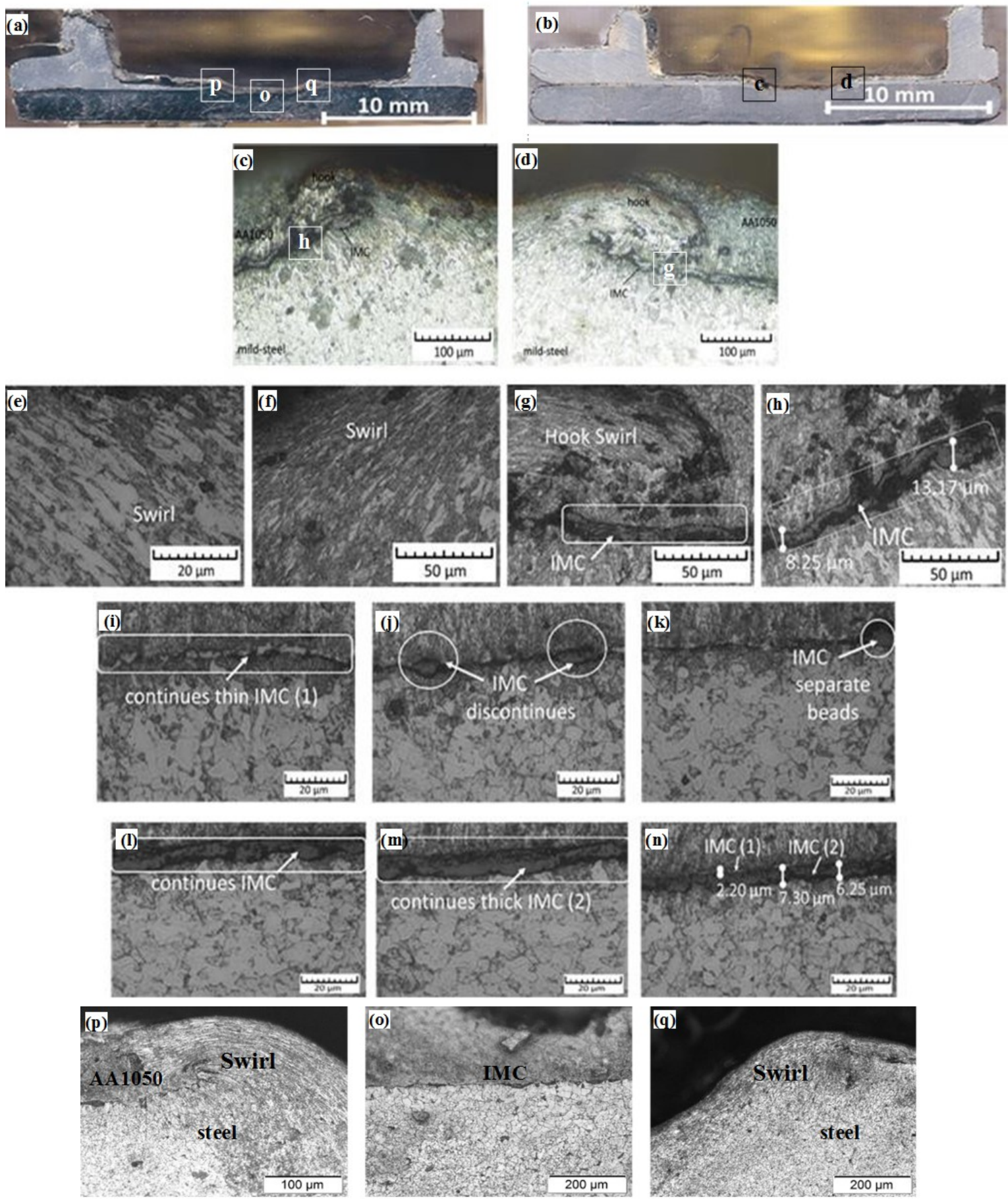

Figure 8. (a,b) Optical macrographs of the FSSWed Al-Steel penetrating joints 400-5-2 and 800- 5-2, respectively. (c-q) Optical microstructures for joint in (b) as follows: (c) left hook, (d) right hook, and (e-f) enlarged swirl structure.(g-h) IMCs at hook.(i) Thin continuous IMCs; (j-k) discontinuous IMCs; (l-m) thick continuous IMCs; (n) thickness of the two phases of IMCs; (h) the hook IMCs. Optical microstructure for joint in (a) microstructure showed as follows: (p) left hook; (q) right hook; and (o) nugget interface. 


\section{Tensile-Shear Test Results}

Tensile-shear test is used to evaluate the FSSW joint strength. The average tensile-shear load for each joint was evaluated based on two tested specimens. Fig. 10 (a) and 10 (b) show the average fracture loads of the welds processed at different welding conditions. It can be observed that the rotation speed and plunge depth have a significant effect on the values of tensile-shear failure load. The tensile shear test results show a significant improvement in the failure load and fracture energy with increasing the plunge depth. These results are in agreement with the reported results (Babu et al., 2012; Masaki et al., 2015). Figure 10 (c) shows maximum tensile strength load carrying capacity varying at different welding conditions (Ataya, 2014b). According to the bar chart in Figure 10 (d), at optimum dwell time, the average failure loads at 400 r.p.m were $1.3 \mathrm{KN}$ and $1.973 \mathrm{KN}$, and then, at 1200 r.p.m, they were $839 \mathrm{~N}$ and 1.188 $\mathrm{KN}$ at $\mathrm{Pd}=1.4 \mathrm{~mm}$ and $\mathrm{Pd}=2.4 \mathrm{~mm}$, respectively. The maximum average failure load increased to $2.15 \mathrm{KN}$ when rotational speed was $800 \mathrm{RPM}$ and $\mathrm{Pd}=2.4 \mathrm{~mm}$ at which the specimen has maximum joint strength value. It can be noted that with increasing the rotational speed, the joint strength increases till optimum value after which the failure load decreased. Also, increasing the penetration depth increases the joint strength. Lathabai et al., Tozaki et al. (Tozaki, Uematsu, and Tokaji, 2010) reported that both the cross-tension and tensile-shear strengths decreased with increasing the tool rotational speed (Mohamed et al., 2021). As the rotational speed increases, the heat input will increase which subsequently gives rise to the grain growth and thereby joint strength decreases (Fereiduni et al., 2016).
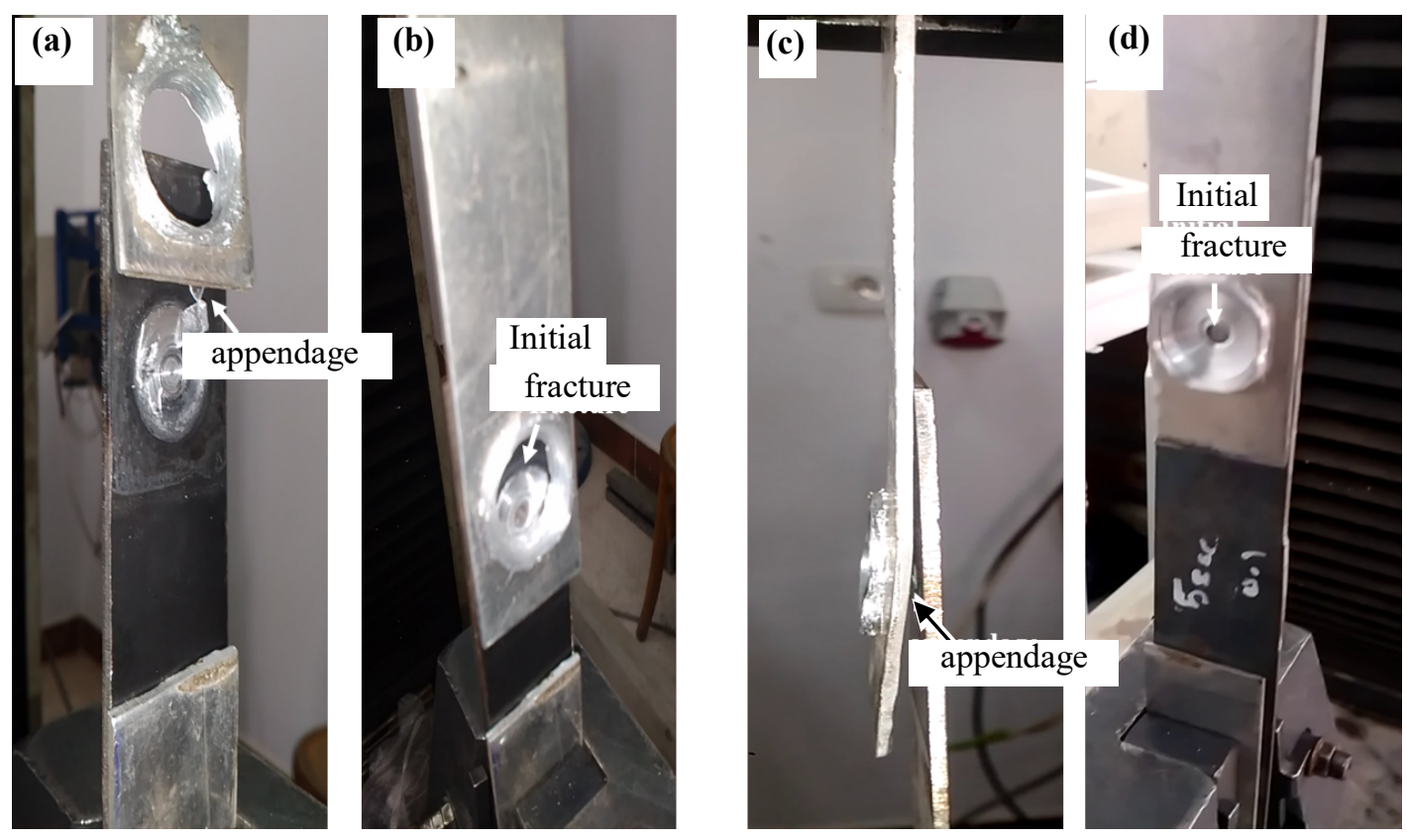

Figure 9. Tensile shear testing of the FSSWed Al/St. showing the different fracture modes in samples welded at conditions 800-5-2 (a, b) and 1200-5 (c, d). (b), (d) are the initial fracture position; (a),(c) are aluminum appendage, where the final fracture occurred. 
(a) Non-Penetrating $(\mathbf{P d}=1.4 \mathrm{~mm})$

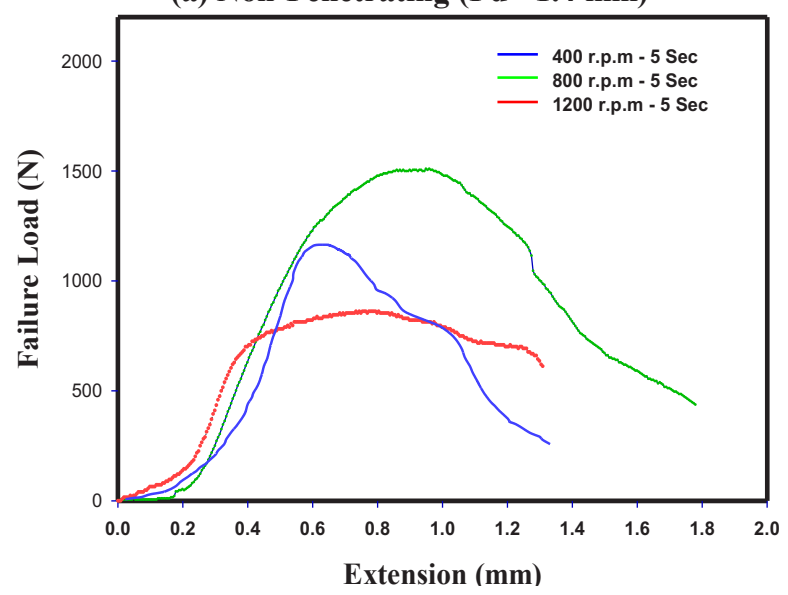

(b) Pentrating $(\mathrm{Pd}=2.4 \mathrm{~mm})$

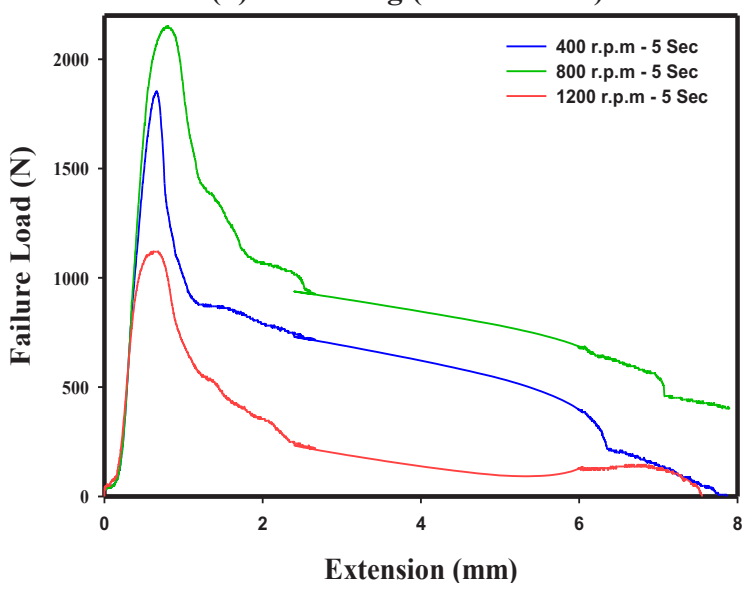

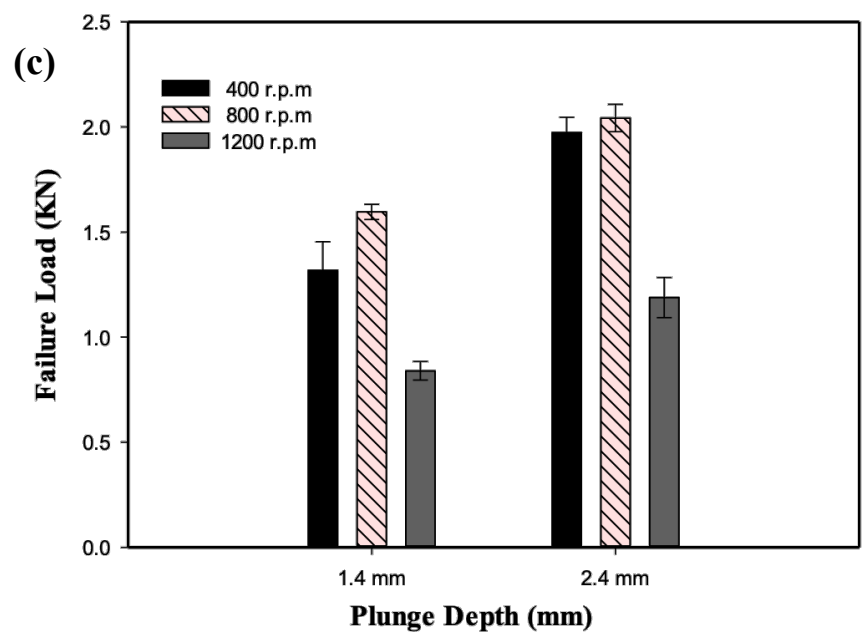

Figure 10. Typical loading curves of joint at different rotational speeds and $5 \mathrm{sec}$ dwell time with (a) nonpenetrating $\mathrm{Pd}=1.4 \mathrm{~mm}$ and (b) penetrating $\mathrm{Pd}=2.4 \mathrm{~mm}$ conditions.(c) Average failure load for each rotational speed for penetrating $(\mathrm{Pd}=2.4 \mathrm{~mm})$ and nonpenetrating $(\mathrm{Pd}=1.4 \mathrm{~mm})$ conditions at optimum dwell time of 5 Sec.

\section{Fractured Mechanism and Failure Mode}

The fracture of the specimens 800-5-2 and 1200-5, which presents the highest and lowest tensile-shear loads, during tensile test, is shown in Fig 9 (a), (b) and Fig. 9 (c), (d), respectively. The fracture surfaces showed two regions. Initial interfacial fracture in Fig. 9 (b) is along the joint interface. Hence, shear surface is shown in Fig. 12 (a), and final shear fracture within aluminum sheet (i.e., the weaker member) is mating appendage surface Fig. 9 (a); elongated appendage designates a suitable bonding between both sheets. The other specimens with $(\mathrm{Pd}=2.4 \mathrm{~mm})$ observed the same features in all fractured joints. They exhibited a skewed surface, shear surface, around the pin projection (Ahmed et al., 2013). The joints welded at $(\mathrm{Pd}=1.4 \mathrm{~mm}$ ) have completed the separation of the sheets and an attached aluminum was exhibited at the pin key-hole as shown in Figure 12 and Table 3. The dominant of the initial and final fracture surfaces at mild steel side is a broken IMC composed of a near-continuous layer with cracks and cleavagetype features (Niroumand-Jadidi and Kashani-Bozorg, 2018). 

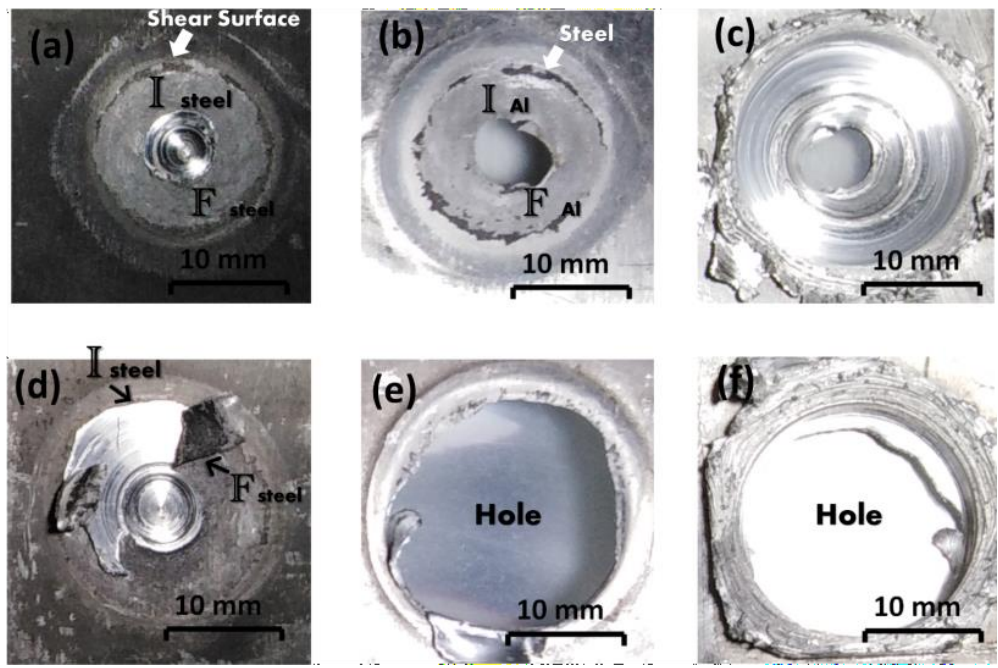

Figure 12. The initial and final fracture points of FSSW Al/St. joints at conditions: 800-5 $[\mathrm{Pd}=1.4 \mathrm{~mm}]$ for $(\mathrm{a}),(\mathrm{b})$, and $(\mathrm{c})$; and $800-5-2[\mathrm{Pd}=2.4 \mathrm{~mm}]$ for $(\mathrm{d}),(\mathrm{e})$, and (f).

Table 3. Joints fracture morphology views from upper and lower sides of mild steel and AA 1050.

\begin{tabular}{|c|c|c|c|c|c|c|c|}
\hline Joint & $\begin{array}{l}\text { Top view of } \\
\text { mild-steel }\end{array}$ & $\begin{array}{l}\text { Back view of } \\
\text { AA } 1050\end{array}$ & $\begin{array}{l}\text { Top view of } \\
\text { AA } 1050\end{array}$ & $\begin{array}{l}\text { Top view of } \\
\text { mild-steel }\end{array}$ & $\begin{array}{c}\text { Back view of } \\
\text { AA } 1050\end{array}$ & $\begin{array}{l}\text { Top view of } \\
\text { AA } 1050\end{array}$ & Joint \\
\hline ஸे & & & & & & & ̛̊̀ \\
\hline 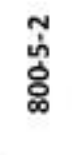 & & & & & & & ઠें \\
\hline $\begin{array}{l}\text { N } \\
\text { ஸे } \\
\text { ర్ల }\end{array}$ & & & & & & & ర్ర్తి \\
\hline
\end{tabular}

According to the literature of FSSW joints, there are two common failure modes, including nugget pull out which is also called plug fracture (PF) and cross nugget failure (Chen, Liu, and Ni, 2017). The former mode is considered as a ductile fracture which experienced a nugget at aluminum appendage where the initial fracture was generated in the cracks that propagate at shoulder interfacial area (weld nugget). The other failure mode is considered as a relatively brittle fracture where the fracture happens across the weld nugget that is why it is called interfacial fracture (IF) (Bozkurt and Bilici, 2013). In this study, the plug fracture failure mode was observed in all specimens with nonpenetrating conditions and (IF) failure mode was observed in penetrating condition specimens, as shown in Table 3. As shown in Figure 13, the plug fracture (PF), which revealed with penetration in the lower steel sheet, has 
a higher energy absorption than the interfacial fracture (IF). As in case of penetration, a more progressive failure results from tearing of the $\mathrm{Al}$ sheet around the nugget which manifests itself in a larger displacement (Chen, Liu, and Prangnell, 2014).

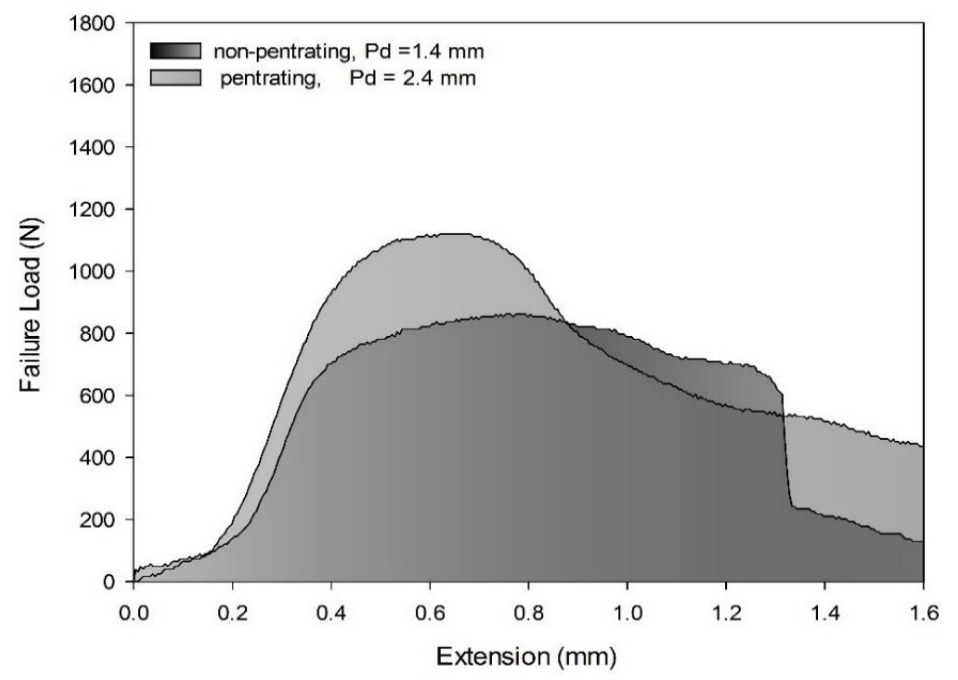

Figure 13. Absorbed energy for nonpenetrating and penetrating area under load displacement curves.

\section{Microhardness Profile}

The Vickers hardness (HV) tests were carried out on the cross-section of the welds lowest and highest joint strength specimens: (a) 1200-5 and (b) 800-5-2, respectively. Microhardness values were taken across the aluminum and mild steel at mid thickness center lines, respectively. From the HV variation profile, it is observed that hardness increased near the joint and then decreased gradually as one moved away to base materials. This is due to the increased stirring action near the joint nugget which influenced more grain refinement as compared to the regions away from it (Swamy and Kiran, 2016; Ahmed et al., 2017; and Ahmed et al., 2021b). As shown in Figures 14 (a), (b), each distribution of hardness values was found to be symmetric with respect to the center of the keyhole.

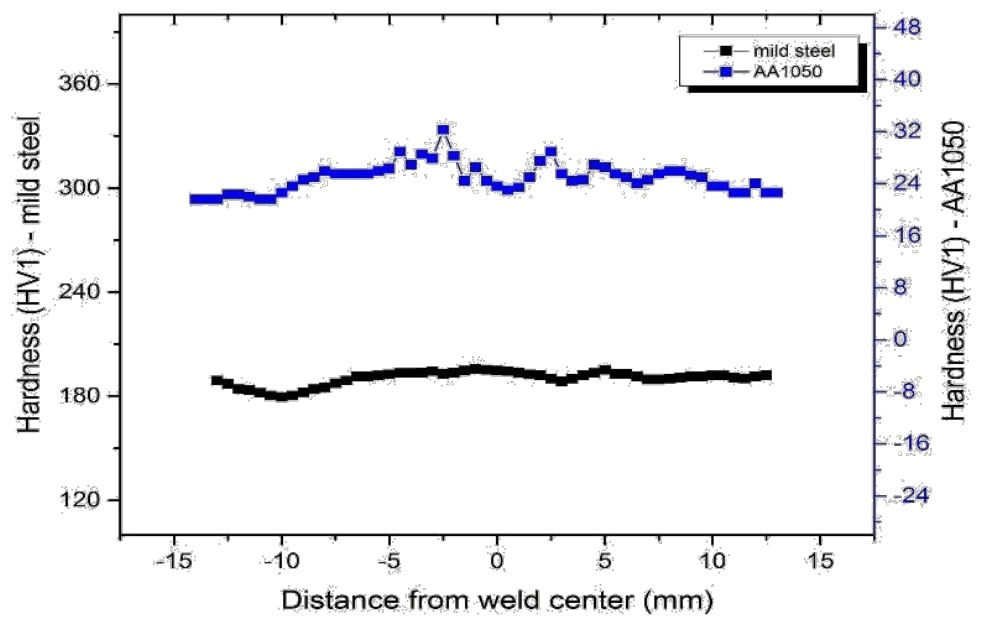

(a) 


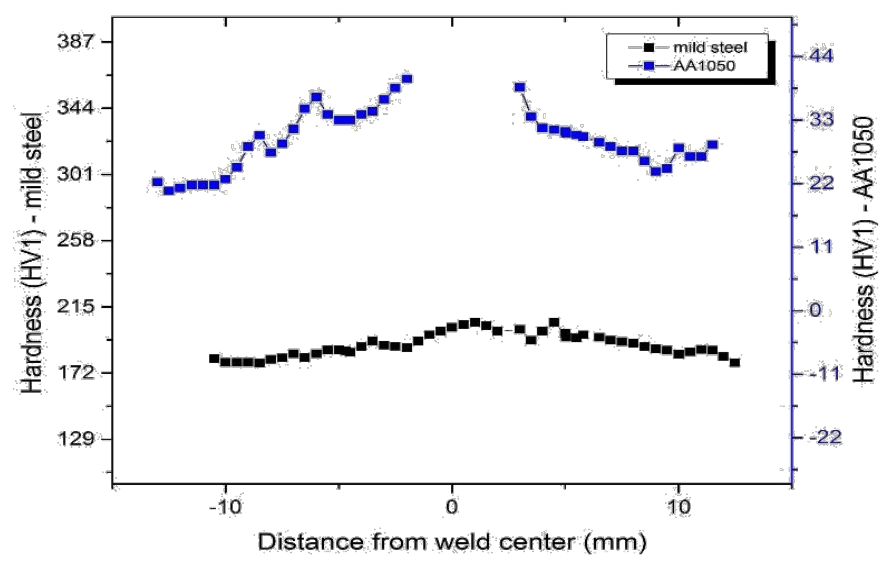

(b)

Figure 14. Microhardness profile for joints specimens: (a) 1200-5 and (b) 800-5-2.

\section{CONCLUSION}

Dissimilar joining using friction stir spot welding (FSSW) technique for 2mm thickness AA1050 and mild steel has been carried out and the following conclusions have been found.

1. Sound FSSWed joints between AA1050 and mild steel are produced in both nonpenetrating $(\mathrm{Pd}=1.4 \mathrm{~mm})$ and penetrating $(\mathrm{Pd}=2.4 \mathrm{~mm})$ cases at optimum dwell time $(5 \mathrm{sec})$ and rotational speed $(400 \mathrm{rpm}, 800 \mathrm{rpm}$, and $1200 \mathrm{rpm})$.

2. Microstructural investigation has revealed that the hook feature with swirl structure of the steel grains in case of penetrating condition, formed mainly due to hook mechanical interlocking, gave high joint strength.

3. As the rotational speed and dwell time increase, the forging effect enhanced the joint interlocking and resulted in strongly bonded joint.

4. The penetration of FSSW tool in the lower sheet changed the fracture mode from interfacial to plug mode.

5. Maximum joint strength is obtained at conditions of rotational speed ( $800 \mathrm{rpm})$, dwell time (5 sec), and penetrating condition $(\mathrm{Pd}=2.4 \mathrm{~mm})$.

\section{ACKNOWLEDGEMENT}

The authors extend their appreciation to the Deputyship for Research \& Innovation, Ministry of Education in Saudi Arabia for funding this research work through the project number (IF-PSAU-2021/01/18022).

\section{REFERENCES}

Abd, M.M., Osman, T.A., Mokadem, A. El \& Bakr, A., 2020. Evaluation of the formation of intermetallic compounds at the intermixing lines and in the nugget of dissimilar steel / aluminum friction stir welds. Integr. Med. Res. 9, 10209-10222. https://doi.org/10.1016/j.jmrt.2020.07.027

Ahmed, M.M.Z., Ahmed, E., Hamada, A.S., Khodir, S.A., El-Sayed Seleman, M.M.\& Wynne, B.P., 2016. Microstructure and mechanical properties evolution of friction stir spot welded high-Mntwinning-induced plasticity steel. Mater. Des. 91. https://doi.org/10.1016/j.matdes.2015.12.001 
Ahmed, M.M.Z., Wynne, B.P., Martin, J.P., 2013. Effect of friction stir welding speed on mechanical properties and microstructure of nickel based super alloy Inconel 718. Sci. Technol. Weld. Join. 18, 680-687. https://doi.org/10.1179/1362171813Y.0000000156

Ahmed, M.M.Z., Ataya, S., El-Sayed Seleman, M.M., Ammar, H.R., Ahmed, E., 2017. Friction stir welding of similar and dissimilar AA7075 and AA5083. J. Mater. Process. Technol. 242, 77-91. https://doi.org/10.1016/j.jmatprotec.2016.11.024

Ahmed, M.M.Z., Ataya, S., El-Sayed Seleman, M.M., Mahdy, A.M.A., Alsaleh, N.A., Ahmed, E., 2021. Heat input and mechanical properties investigation of friction stir welded aa5083/aa5754 and aa5083/aa7020. Metals (Basel). 11, 1-20. https://doi.org/10.3390/met11010068

Ahmed, M.M.Z., El-Sayed Seleman, M.M., Zidan, Z.A., Ramadan, R.M., Ataya, S., Alsaleh, N.A., $2021 b$. Microstructure and mechanical properties of dissimilar friction stir welded AA2024-T4/AA7075-T6 T-butt joints. Metals (Basel). 11, 1-19. https://doi.org/10.3390/met11010128

Ahmed, M.M.Z., Wynne, B.P., Rainforth, W.M., Addison, A., Martin, J.P., Threadgill, P.L., 2019. Effect of Tool Geometry and Heat Input on the Hardness, Grain Structure, and Crystallographic Texture of ThickSection Friction Stir-Welded Aluminium. Metall. Mater. Trans. A 50, 271-284. https://doi.org/10.1007/s11661-018-4996-2

Ataya, S., 2014a. LOAD CARRYING CAPACITY AND MICROSTRUCTURE OF RESISTANCE SPOT WELDED DUAL-PHASE (DP600) STEEL, in: John S. Carpenter, Chenguang Bai, Jiann-Yang Hwang, S.I. (Ed.), Characterization of Minerals, Metals, and Materials. pp. 297-304. https://doi.org/https://doi.org/10.1002/9781118888056.ch35

Aota, K., Takahashi, M. \& Ikeuchi, K., 2010.Friction stir spot welding of aluminium to steel by rotating tool without probe. Weld. Int. 24, 96-104. https://doi.org/10.1080/09507110902843057

Babu, S., Janaki Ram, G.D., Venkitakrishnan, P. V., Reddy, G.M.\& Rao, K.P., 2012. Microstructure and Mechanical Properties of Friction Stir Lap Welded Aluminum Alloy AA2014. J. Mater. Sci. Technol. 28, 414-426. https://doi.org/10.1016/S1005-0302(12)60077-2

Bozkurt, Y. \& Bilici, M.K., 2013.Application of Taguchi approach to optimize of FSSW parameters on joint properties of dissimilar AA2024-T3 and AA5754-H22 aluminum alloys. Mater. Des. 51, 513-521. https://doi.org/10.1016/j.matdes.2013.04.074

Bozzi, S., Etter, A.L., Baudin, T., Robineau, A.\& Goussain, J.C., 2008. Mechanical Behaviour and Microstructure of Aluminum-Steel Sheets Joined by FSSW 2008. https://doi.org/10.1155/2008/360617

Bozzi, S., Helbert-Etter, A.L., Baudin, T., Criqui, B.\& Kerbiguet, J.G., 2010. Intermetallic compounds in Al 6016/IF-steel friction stir spot welds. Mater. Sci. Eng. A 527, 4505-4509. https://doi.org/10.1016/j.msea.2010.03.097

Chen, K., Liu, X. \& Ni, J., 2017.Effects of process parameters on friction stir spot welding of aluminum alloy to advanced high-strength steel. J. Manuf. Sci. Eng. Trans. ASME 139. https://doi.org/10.1115/1.4036225

Chen, Y.C., Liu, S.F. \& Prangnell, P., 2014. Influence of galvanized coatings on abrasion circle friction stir spot welding aluminium to steel for automotive applications. Mater. Sci. Forum 783-786, 1741-1746. https://doi.org/10.4028/www.scientific.net/msf.783-786.1741

Fereiduni, E., Movahedi, M.\& Kokabi, A.H., 2016. Dissimilar Al/steel friction stir spot welding: To penetrate into the lower steel sheet or not? Sci. Technol. Weld. Join. 21, 466-472. https://doi.org/10.1080/13621718.2015.1125407 
Figner, G., Vallant, R., Weinberger, T., Schröttner, H., Paśič, H.\&Enzinger, N., 2009.Friction Stir Spot Welds between aluminium and steel automotive sheets: Influence of welding parameters on mechanical properties and microstructure. Weld. World 53. https://doi.org/10.1007/BF03266697

Hamada, A.S., Järvenpää, A., Ahmed, M.M.Z., Jaskari, M., Wynne, B.P., Porter, D.A., Karjalainen, L.P., 2015. The microstructural evolution of friction stir welded AA6082-T6 aluminum alloy during cyclic deformation. Mater. Sci. Eng. A 642, 366-376. https://doi.org/10.1016/j.msea.2015.06.100

Hoziefa, W., Toschi, S., Ahmed, M.M.Z., Morri, A., Mahdy, A.A., El-Sayed Seleman, M.M., El-Mahallawi, I., Ceschini, L., Atlam, A., 2016. Influence of friction stir processing on the microstructure and mechanical properties of a compocast AA2024-A12O3 nanocomposite. Mater. Des. 106, 273-284. https://doi.org/10.1016/j.matdes.2016.05.114

Jordon, J.B., Rao, H., Amaro, R.\& Allison, P., 2019. Introduction to Fatigue in Friction Stir Welding, in: J. Brian Jordon, Robert Amaro, Paul Allison, Harish Rao (Eds.), Fatigue in Friction Stir Welding. ButterworthHeinemann, pp. 1-8. https://doi.org/10.1016/b978-0-12-816131-9.00001-5

Khodir, S.A., Ahmed, M.M.Z., Ahmed, E., Mohamed, S.M.R.\& Abdel-Aleem, H., 2016. Effect of Intermetallic Compound Phases on the Mechanical Properties of the Dissimilar Al/Cu Friction Stir Welded Joints. J. Mater. Eng. Perform. 25. https://doi.org/10.1007/s11665-016-2314-y

Mahgoub, Ak., Bazoune, A., Shuaib, Abdel Rahaman\& Merah, N., 2015. Friction Stir Spot Welding: Experimental Investigation and Numerical Modeling. King Fahd University of Petroleum and Minerals, Dhahran, Saudi Arabia.

Mahto, R.P., Bhoje, R., Pal, S.K., Joshi, H.S.\& Das, S., 2016. A study on mechanical properties in friction stir lap welding of AA 6061-T6 and AISI 304. Mater. Sci. Eng. A 652, 136-144. https://doi.org/10.1016/j.msea.2015.11.064

Yuichiro, T., Katashi, M., Toshiaki, Y.\& Masahiro, F., 2015. Fatigue behaviour of aluminium alloy/steel joints by spot friction stirring. Weld. Int. 29, 96-102. https://doi.org/10.1080/09507116.2012.753252

Mohamed, M., Ahmed, Z., Ataya, S., Seleman, M.M.E., Allam, T., 2021. Grain Structure , Crystallographic Texture, and Hardening Behavior of Dissimilar Friction Stir Welded AA5083-O and 1-17.

Niroumand-Jadidi, A.\& Kashani-Bozorg, S.F., 2018.Microstructure and property assessment of dissimilar joints of 6061-T6 Al/dual-phase steel fabricated by friction stir spot welding. Weld. World 62, 751-765. https://doi.org/10.1007/s40194-018-0602-x

Piccini, J.M.\& Svoboda, H.G., 2015. Effect of pin length on Friction Stir Spot Welding (FSSW) of dissimilar Aluminum-steel joints. Procedia Mater. Sci. 9, 504-513. https://doi.org/10.1016/j.mspro.2015.05.023

Reza-E-Rabbya, M., Rossa, K., McDonnellb, M., Scott, A.W., 2020. Numerical simulation and experimental validation of joint performance in aluminum-steel lap welds formed by friction stir dovetailing. J. Mater. Process. Tech. 277, 116459. https://doi.org/10.1016/j.jmatprotec.2019.116459

Swamy, M.M.\& Kiran, S.M.K., 2016. A Study on Friction Stir Multi Spot Welding Techniques to Join Commercial Pure Aluminum and Mild Steel Sheets. Trans. Indian Inst. Met. https://doi.org/10.1007/s12666016-0916-6

Tozaki, Y., Uematsu, Y.\& Tokaji, K., 2010. A newly developed tool without probe for friction stir spot welding and its performance. J. Mater. Process. Technol. 210, 844-851. https://doi.org/10.1016/j.jmatprotec.2010.01.015

Yang, X.W., Fu, T.\& Li, W.Y., 2014.Friction stir spot welding: A review on joint macro- and microstructure, property, and process modelling. Adv. Mater. Sci. Eng. https://doi.org/10.1155/2014/697170 